\title{
C9orf72 Gene
}

National Cancer Institute

\section{Source}

National Cancer Institute. C9orf72 Gene. NCI Thesaurus. Code C101398.

This gene may play a role in cell death. 